\section{Phosphoethanolamine: anticancer pill bandwagon effect}

Fosfoetanolamina: surfando na onda da pílula do câncer

Fosfoetanolamina: la píldora anticáncer y su efecto arrastre

Francisco José Roma Paumgartten 1

\author{
1 Escola Nacional de Saúde Pública Sergio Arouca, \\ Fundação Oswaldo Cruz, Rio de Janeiro, Brasil.

\section{Correspondence} \\ F. J. R. Paumgartten \\ Laboratório de Toxicologia Ambiental, Escola Nacional \\ de Saúde Pública Sergio Arouca, Fundação Oswaldo \\ Cruz. \\ Rua Leopoldo Bulhões 1480, Rio de Janeiro, \\ RJ 21041-210, Brasil. \\ paum@ensp.fiocruz.br
}

http://dx.doi.org/10.1590/0102-311X00135316

Alves et al. ${ }^{1}$ commented that a "clamor by society" took precedence over the scientific evidence in the approval of Law 13,269/2016 that authorizes the production, prescription and dispensing of synthetic phosphoethanolamie ("phospho") pills to cancer patients. As emphasized by the authors, no clinical trial supports the alleged anticancer efficacy of the "phospho" pill. After the article was published, a temporary decision by the Federal Supreme Court (STF) - by a 6 to 4 vote - suspended the effectiveness of Law $13,269 / 2016$ until a final court decision is reached. The six ministers who voted to suspend the law mentioned the lack of clinical studies in their votes. It is noteworthy that the chemists at the University of São Paulo's campus in São Carlos, who manufactured "phospho" pills and distributed them to patients, presented no clinical documentation (patient records or case reports) to substantiate their claims about the efficacy of the anticancer pill. Moreover, preclinical in vitro (toxicity to some tumor cell lines) and in vivo tests (rodent xenograft tumor growth assays) on a possible antitumor activity of "phospho" yielded disappointing results. Despite the lack of experimental and clinical evidence for anticancer efficacy of the "phospho" pill, its reputation as a drug effective against otherwise untreatable advanced cancers rapidly spread among patients out of therapeutic possibility. Patients and relatives started to see "phospho" as the last hope of salvation. Needless to say, desperately ill patients and their relatives are a group of people particularly vulnerable to groundless therapeutic claims.

The overwhelming acceptance of unproved but popular ideas - or bandwagon effect - is a social psychology phenomenon that is not limited to politics, consumer behavior, social customs or public opinion. Medical bandwagons are relatively common phenomena 2,3 and the current popular belief regarding the effectiveness of the "phospho" pill against malignant tumors is typically one more of these cases. The uniqueness of this story, however, resides on the fact that a majority of Brazilian politicians and incumbent government authorities hopped on the "phospho" pill bandwagon. Not only did Congress overwhelmingly pass the "phospho" bill but the President also promptly signed it into law (with no veto) overlooking recommendations to the contrary by the Brazilian Health Regulatory Agency (Anvisa), the Brazilian Society for the Advancement of Science (SBPC) and the country's main medical association (AMB). Furthermore, the National Committee on Research Ethics authorized (in March 2016) the onset of a "phospho" trial in cancer patients sponsored by the São Paulo State Secretary of Health. This was an amazing decision because sponsors did not provide scientifically valid nonclinical (or clinical) evidence of "phospho" potential benefits to cancer patients nor did they present an adequate set of preclinical safety data.

The authorization to test a new drug in patients in the absence of evidences of potential therapeutic usefulness and without a comprehensive preclinical safety evaluation breaks a cornerstone rule of human research ethics. According to internationally-accepted ethical principles (Declaration of Helsinki, paragraph 11) “...clinical testing must be preceded by adequate laboratory or animal experimentation to demonstrate a reasonable probability of success without undue risks" 4 (p. 47). It is unclear why the National Committee on Research Ethics exempted "phospho" from a preclinical evaluation, thereby making a worrisome case-law for further clinical trial applications. Based on social psychology studies one could expect that bandwagon effect might influence political decisionmaking. Nonetheless, it is also expected that ethical review committees stick firmly to prevailing ethical principles and by doing so are uninfluenced by fads and bandwagon effects in decision-making. 
1. Alves SMC, Delduque MC, Santos AO. Law 13,269/2016: clamor by society trumps the scientific method! Cad Saúde Pública 2016; 32:e00070116.

2. Cohen L, Rothschild H. The bandwagons of medicine. Perspect Biol Med 1979; 22:531-8.

3. Rikkers LF. The bandwagon effect. J Gastrointest Surg 2002; 6:787-94.

4. Council for International Organizations of Medical Sciences/World Health Organization. International ethical guidelines for biomedical research involving human subjects. Geneva: Council for International Organizations of Medical Sciences; 2002.

Submitted on $01 / \mathrm{Aug} / 2016$

Approved on 24/Aug/2016

\section{The authors reply}

As autoras respondem

Las autoras responden

Sandra Mara Campos Alves 1,2 Maria Célia Delduque 1,2

Alethele Oliveira Santos 1

1 Universidade de Brasília, Brasília, Brasil

2 Fundação Oswaldo Cruz, Brasília, Brasil

Correspondence

S. M. C. Alves

SQN 111, bloco F, apto. 208, Asa Norte, Brasília DF

70.754-060, Brazil.

smcalves@gmail.com

The article entitled Law 13,269/2016: Clamor by Society Trumps the Scientific Method!, published in the issue of June 2016, debated an important question that has repercussions beyond phosphoethanolamine per se ${ }^{1}$. The issue is use of the scientific method to back public policymakers' decisions.

In the specific case of synthetic phosphoethanolamine (the so-called "cancer pill”), the debate gained public attention because it touched on protection of life, since the substance's principal beneficiaries argued that they had no other alternative for treating their illness. This social clamor was mentioned in a Letter to the Editors as the "medical bandwagon effect", highlighting the fact that public policymakers are not always immune to the pressure and influence of issues with major social repercussions.

The Letter to the Editors also mentions that the ruling by the Brazilian National Commission on Research Ethics (CONEP) approved the clinical protocol to allow testing the substance in human beings to begin without "an adequate set of preclinical safety data", thus disregarding basic ethical principles for research in human subjects. This concern merits attention, since the ruling can be considered a precedent for the approval of other protocols in defiance of this overarching set of principles and standards involved in such a sensitive question.

What is certain is that diseases are not divine punishment and should be viewed and treated in light of science (Hippocrates, 4 th century BC) 2 . In the post-modern world, the advancement of science should not be pursued by any means or method or at any cost. Humankind has already experienced unreasoned practices and procedures, and to avoid repeating historical episodes, clinical research is based on the Declaration of Helsinki (1964). Science is irreplaceable for guaranteeing the right to health.

The fact is that the Brazilian National Congress passed and the President signed Law 13,269/2016 3 Congress argued on the basis of the product's purported low toxicity, "control" of a parallel market, and quality of life for patients. The President justified signing the law as an exception to the prevailing legislation, given the social repercussions, despite acknowledging the need for clinical research. Therefore, 
neither the Legislative nor the Executive branches honored their Constitutional duty to safeguard the people's health, as duly expressed in article 196 of the 1988 Federal Constitution, i.e., it is the duty of the state to develop public policies to reduce diseases and to promote, protect, and reclaim health.

In light of the above, other arguments were drawn into the debate. The first relates to the expression coined by Dr. Paulo Hoff in the public hearing on health in 2009 in the Brazilian Supreme Court "hope-based medicine". According to the oncologist, "unproven medications are occasionally used by physicians and patients in desperate situations", as in patients diagnosed with terminal cancer. Still, Hoff (Audiência Pública da Saúde. http://www.stf.jus. $\mathrm{br} /$ arquivo/cms/processoAudienciaPublicaSaude/ anexo/Marcelo_Hoff.pdf, accessed on 19/Sep/2016) emphasized that "such practice should not be encouraged" and that "expenditures on these medications are difficult to justify in the public system".

In this sense, medication not registered with the Brazilian Health Regulatory Agency (Anvisa), in flagrant violation of Law 6,360/1976 4, not only places patients at risk but also compromises resources that would otherwise benefit society as a whole. As the saying goes, both the Legislative and the Executive were "playing to the crowd".

This understanding is reinforced by another Brazilian oncologist, Dr. Raul Cutait, interviewed by a mainstream newspaper, discussing the waiver of registration for phosphoetanolamine. Cutait was incisive in stating that hope should be part of prescriptions in the physician-patient partnership, in the struggle against diseases, but that it should never be offered without scientific validation: "otherwise one runs the risk of promoting quackery" 5

From this perspective, Supreme Court Justice Marco Aurélio Mello, presiding over the ruling on the injunction discussed in the Letter to the Editor, stated, "The hope invested by society in medicines, especially for treating diseases like cancer, cannot distance itself science" 6 .
This point highlights the transitory nature of science, whose change must always be subject to analysis. In the case of patient safety and medicines, such analysis is certainly not the responsibility of the National Congress. Safety analysis must be performed by an expert agency, in Brazil's case the Anvisa.

The broader debate at stake here is Anvisa's jurisdiction versus the circulation and consumption of unregistered medicines in the country - having found backing in social clamor, in the lawmaking power of the National Congress, and in a judge's ruling.

The Brazilian Supreme Court is currently reviewing a case dealing with the supply, by government, of medicines not registered with Anvisa ( $R E$ 657,718/ $M G-R G$ ). The presiding judge in the case, Justice Marco Aurélio Mello, in declaring his vote, acknowledged the need for scientific consensus, which according to the legal grounds in Brazilian cases is attested by the product's registration with Anvisa.

Justice Mello stated: "To rule otherwise would mean to allow laboratory experiments for therapies whose clinical benefits and treatment costs escape the control of public authorities. In the ultimate analysis it would mean authorizing pharmaceutical experimentalism at the expense of society, which finances public health through taxes and contributions" 9.

The Supreme Court's review of case RE 657,718/ MG-RG, which began on September 16, 2016, was temporarily suspended when Justice Luís Roberto Barroso requested a detailed review of the briefs. The situation calls for a state of vigilance concerning future votes on the case and the Supreme Court's final ruling.

May the scientific paradigm prevail! 
1. Alves SMC, Delduque MC, Santos AO. Lei no 13.269/2016: a comoção da sociedade vence o método científico! Cad Saúde Pública 2016; 32:e0070116.

2. Littré E. Oeuvres complètes d'Hippocrate. v. I. Paris: J B Bailliere; 1839.

3. Brasil. Lei no 13.269, de 13 de abril de 2016. Autoriza o uso da fosfoetanolamina sintética por pacientes diagnosticados com neoplasia maligna. http://www.planalto.gov.br/ccivil_03/_Ato20152018/2016/Lei/L13269.htm (accessed on 15/ Apr/2016).

4. Brasil. Lei no 6.360 de 23 de setembro de 1976 . Dispõe sobre a Vigilância Sanitária a que ficam sujeitos os Medicamentos, as Drogas, os Insumos Farmacêuticos e Correlatos, Cosméticos, Saneantes e Outros Produtos, e dá outras providências. http://www.planalto.gov.br/ccivil_03/leis/L6360. htm (accessed on 14/Sep/2016).
5. Cutait R. Câncer: esperança e ciência. Folha S. Paulo. http://www1.folha.uol.com.br/opiniao/ 2016/05/1772719-cancer-esperanca-e-ciencia. shtml. (accessed on 19/Sep/2016).

6. Superior Tribunal Federal. Ação Direta de Inconstitucionalidade no 5.501 de 2016. http://www.stf. jus.br/arquivo/cms/noticiaNoticiaStf/anexo/ adi5501MMA.pdf (accessed on 16/Sep/2016).

7. Superior Tribunal Federal. Recurso Extraordinário no 657.718/MG-RG. http://www.stf.jus.br/arqui vo/cms/noticiaNoticiaStf/anexo/adi5501MMA. pdf (accessed on 16/Sep/2016). 